\title{
EFFECT OF SOME FERTILIZATION TREATMENTS ON GROWTH OF TREES, PRODUCTIVITY AND QUALITY OF GUAVA (Psidium guajava I.) FRUITS CV. "ETMANI". II. UNDER FASTING SYSTEM. Osman, I.M.S. ; A.A. Al-Taweel and E.G. Mekhiel Olive and Fruits of Semiarid Zone Dept., Hort. Res. Inst., ARC, Giza, Egypt.
}

\begin{abstract}
A series of field experiments was carried out in a private orchard at Qalyob region, Qalubia governorate, Egypt during 2011/12, 2012/13 and 2013/14 seasons for winter production of 9-years-old guava (Psidium guajava L.) cv. "Etmani" trees, planted on clay loam soil at a distance of $5 \times 5 \mathrm{~m}$ and fasted from April, $1^{\text {st }}$ to July end, beside improving yield and quality of such winter crop by application of organic compost at either full, $3 / 4$ or $1 / 2$ the recommended dose $(40,30$ and $20 \mathrm{~kg} / \mathrm{tree}$, respectively) + both feldspar and rock phosphate at either full, $3 / 4,1 / 2$ or $1 / 4$ the recommended dose for each + biofertilizer mixture comprising nitropeine + phosphoreine + potasseine at the recommended dose for each, where all previous compost were arranged in 12 combinations plus the control.

The gained results have shown that most fertilization treatments employed in this work raised the means of shoot length, number of leaves $/ \mathrm{m}$, leaf area and number of flower buds/m over those of control with various significant levels in the 3 seasons. Similarly, were those results of No. of fruits $/ \mathrm{m}$, fruit weight, yield, fruit length, diameter and volume, as well as flesh thickness. The prevalence in all aforenamed characters was for the combination of $75 \%$ compost $+100 \%$ feldspar $+100 \%$ rock phosphate + biofertilizers mixture which gave the utmost high means over control and other combinations in most cases of the three seasons. The percent of TSS was significantly increased in the first season only by $100 \%$ compost $+25 \%$ feldspar +25 $\%$ rock phosphate + biofertilizers mixture combined treatment, but in the $2^{\text {nd }}$ and $3^{\text {rd }}$ seasons, it was slightly improved by the different used combinations with nonsignificant differences in between or with control. The acidity \% exhibited a similar behaviour in the three growing seasons, but the least percent of acidity was found due to the combining between $100 \%$ compost, $25 \%$ feldspar $+25 \%$ rock phosphate and biofertilizer mixture $\left(\mathrm{T}_{4}\right)$, especially in the $1^{\text {st }}$ and $2^{\text {nd }}$ seasons. In the $3^{\text {rd }}$ season, however, the least acidity $\%$ was attained by $75 \%$ compost $+100 \%$ feldspar $+100 \%$ rock phosphate + biofertilizer nixture (T5). So, the best ratio of TSS/acidity was obtained in the first and second seasons by $T_{4}$, while in the $3^{\text {rd }}$ one by $T_{5}$. Vitamin $C$ content and flesh thickness were also improved by the used fertilization combinations, but the highest records of them was obtained by different treatment in every season. The percent of $\mathrm{N}, \mathrm{P}, \mathrm{K}, \mathrm{Ca}$ and $\mathrm{Mg}$ in the leaves of fertilized plants was, in general improved over that of control in the three seasons by the different used treatments, but no one of them had the superior effect over the others.

Hence, it can be advised to fertilize the 9-years-old trees of guava cv. "Etmani" grown on clay loam soil at $5 \times 5 \mathrm{~m}$ apart under Qalubia governorate conditions and fasted from April, $1^{\text {st }}$ to end of July with $75 \%$ of recommended compost dose (30 $\mathrm{kg} / \mathrm{tree})+100 \%$ of both feldspar $(1.2 \mathrm{~kg} /$ tree $)$ and rock phosphate dose $(1.3 \mathrm{~kg} / \mathrm{tree})$ plus biofertilizer mixture used in this study to get the highest and best quality winter crop from point of commercial and economic view.
\end{abstract}




\section{INTRODUCTION}

Guava (Psidium guajava L.) is still one of the most cheap and popular fruits in Egypt, as it used for both fresh consumption and processing. It excels most other fruit trees in productivity, hardiness, adaptability and rich in vitamin $\mathrm{C}$ and some minerals useful for human health. Besides its high nutritive value, it bears heavy crop every year and gives good economic returns involving very little cost (Thonte and Chakrawar, 1982).

The main guava crop usually appears in Egyptian local markets in summer, in which the fruits are in low quality because they are affected by high temperature, which causes browning of colour, fast decay and short shelf life ( ElBaz et al 2011). So, it was urgent to identify a modern, innovative and more suitable methods to overcome these problems, one of such methods may be fasting (Singh, 2007). Some efforts were done in order to late guava production to winter. In this connection, Mikhail et al., (2007) revealed that shoot length, No. of leaves and fruit set of 10-years-old guava trees were significantly increased as affected by fasting till July, $15^{\text {th }}$ more than fasting till August, $15^{\text {th }}$, whereas fruit weight, flesh thickness and yield were significantly increased by fasting till August, $15^{\text {th }}$ than that till July, $15^{\text {th }}$. The seed $\%$ of August fasting was markedly reduced than that of July one. The early fasting surpassed the late one in vitamin $\mathrm{C}$ and tannins contents, while TSS and TSS/acid ratio were increased more in the fruits of late fasting than the early one. Furthermore, El-Shobaky (2007) and El-Baz et al., (2011) who found that irrigation at $1^{\text {st }}$ June or July greatly raised firmness, TSS, total sugars, acidity, vitamin $\mathrm{C}$ and phenol contents in common guava fruits, but decreased yield compared to irrigation at mid February or $1^{\text {st }}$ April and May. In general, the least decay \% and high quality of fruits obtained from late irrigation at $1^{\text {st }}$ June or July and that gave high price covered greatly the reduce in the yield.

Summer crop is usually affected with attack of fruitfly due to which most of the fruits are destroyed and does not remain marketable. On the other side, the winter crop is free from such attack and good quality fruits are produced. But due to bumper crop in summer season, the trees become exhausted and as a result the bearing of winter crop is seriously affected. If proper nutrient level of soil and trees is maintained for winter crop, we can get improved production (Muhammad et al., 2000). Hence, in order to get good winter crop, we must be use organic and inorganic manures in combination to score better results. In this regard, Muhammad et al., (2000) observed that combined application of farmyard manure and NPK increased the fruit size, weight and total yield of winter crop of guava. Dashora et al., (2007) found that the maximum days taken to initiation of flowering, maximum No. fruits/shoot, maximum fruit set, highest fruit retention and maximum yield of winter crop of guava cv. Sardar were recorded in vermicompost $(1 \mathrm{~kg} /$ tree $)+50 \%$ recommended dose of NPK + PSB (10 g/tree) treatment as compred to control.

Similar results were also discovered on winter crop of guava by Bshir et al., (2009), El-Sharkawy and Osman (2009), Dwivedi et al., (2012) and Elmehart et al., (2012) whom claimed that combining between $75 \%$ recommended NPK fertilizers and biofertilizers (PGPR) at $9.52 \mathrm{l} /$ ha gave the best results for weight 
loss, decreasing firmness and decay, increasing vitamin C, TSS, sugars, improve colour and decreasing total acidity as compared to fruits of untreated trees.

To reduce both high costs and environmental pollution of using mineral fertilizers, many researches resorted to new attitude by using organic manures and biofertilizers instead of chemical ones. This was documented on common guava by Mitra et al., (2010), Wali et al., (2011), Barue et al., (2011), Devi et al., (2012), Yadav et al., (2013), Hernandez et al., (2013), Binepal et al., (2013), Nunes et al., (2014)and Ram et al., (2014), as they all affirmed that the combined application of organic and inorganic manures along with biofertilizers gave better results than their individual application giving better economic response.

The purpose of this study is to investigate the role of fasting in turning the summer crop of guava cv. "Etmani" to winter one plus improving yield and quality of such winter crop by organic compost and mineral rocks in presence of biofertilizers to be more suitable for local marketing and export.

\section{MATERIALS AND METHODS}

Three field experiments were undertaken in a private orchard at Qalyob region, Qalubia governorate, Egypt throughout the three successive seasons of 2011/12, 2012/13 and 2013/14 to study the effect of fasting on lating flowering and fruiting of guava (Psidium guajava L.) cv. "Etmani" trees, and to determine the best combined treatment of organic compost, rocks and biofertilizers necessary for improving fruit yield and quality of the resulted winter crop.

Table (1): The mechanical, physical and chemical properties of the studied soil in the 3 seasons.

\begin{tabular}{|c|c|c|}
\hline Property & & Values \\
\hline \multirow{4}{*}{ Mechanical analysis } & Coarse sand & $7.41(\%)$ \\
\hline & Lime Sand & $23.71(\%)$ \\
\hline & Silt & $28.89(\%)$ \\
\hline & Clay & $30.72(\%)$ \\
\hline Texture (physical) & \multicolumn{2}{|c|}{ Clay loam } \\
\hline \multirow{6}{*}{ Chemical analysis } & $\mathrm{pH}$ & 7.62 \\
\hline & E.C. $(\mathrm{dSm}-1)$ & 3.1 \\
\hline & O.C. & 0.71 \\
\hline & O.M. & $1.24(\%)$ \\
\hline & T. N. & 0.17 \\
\hline & W.H.C. & 54.32 \\
\hline \multirow{6}{*}{ Anions and Cations (meq L-1) } & Bicarbonate $\left(\mathrm{HCO}_{3}{ }^{-}\right)$ & 8.4 \\
\hline & Chloride $\left(\mathrm{Cl}^{-}\right)$ & 11.71 \\
\hline & Sulphate $\left(\mathrm{SO}_{4}^{--}\right)$ & 16.43 \\
\hline & Calcium $\left(\mathrm{Ca}^{++}\right)$ & 8.53 \\
\hline & Magnesium $\left(\mathrm{Mg}^{++}\right)$ & 2.57 \\
\hline & Sodium $\left(\mathrm{Na}^{+}\right)$ & 22.93 \\
\hline
\end{tabular}

Soil analysis was done by: Soil, Water and Environment Res. Inst., ARC, Giza Egypt.

Thus, homogenous trees of 9-years-old planted on clay loam soil at $5 \mathrm{x}$ $5 \mathrm{~m}$ apart and received the regular cultural practices were forced to flowering in September by preventing the surface irrigation for 4 months, commencing 
from first of April to end of July for each season. After fasting, the foliage was manually dropped and the soil was digged, fertilized and irrigated. Fruits were harvested during the period from mid- February to end of March.

The fertilization was accomplished using the following materials at the recommended doses: Al-Obour compost (40 kg/tree), feldspar $(1.2 \mathrm{~kg} / \mathrm{tree})$ and rock phosphate $(1.3 \mathrm{~kg} /$ tree). The physical and chemical analysis of the soil and Al-Obour compost were determined and illustrated in Tables (1 and 2 respectively), while those of feldspar and rock phosphate are shown in Table (3).

Table (2): Physical and chemical analysis of Al-Obour compost used in the three seasons.

\begin{tabular}{|l|c|}
\hline \multicolumn{2}{|c|}{ Al-Obour compost } \\
\hline Character & Content \\
\hline Weight of $/ \mathrm{m}^{3}(\mathrm{~kg})$ & $500-550$ \\
\hline Humidity $\%)$ & $25-30$ \\
\hline $\mathrm{pH}(1-2.5)$ & $7.5-8.0$ \\
\hline Ec $(1: 5)$ & $3 .-4$ \\
\hline Water hold capacity & $250-300 \%$ \\
\hline Total nitrogen & $1-1.4 \%$ \\
\hline Organic matter & $34-38 \%$ \\
\hline Organic carbon & $19.8-22 \%$ \\
\hline C/N ratio & $1-14.2$ \\
\hline NaCl & $1.1-1.25 \%$ \\
\hline Total phosphorus & $0.5-0.75 \%$ \\
\hline Total potassium & $1.25-1.75 \%$ \\
\hline Fe (ppm) & $1500-1800$ \\
\hline $\mathrm{Mn}(\mathrm{ppm})$ & $25-50$ \\
\hline $\mathrm{Cu}(\mathrm{ppm})$ & $50-75$ \\
\hline $\mathrm{Zn}(\mathrm{ppm})$ & $150-225$ \\
\hline
\end{tabular}

The used compost manufactured from residues and free from heavy minerals and pollution. Compost analysis by: Producer Company.

Table (3): The chemical analysis of feldspar and rock phosphate used in the three seasons.

\begin{tabular}{|l|c|c|c|c|}
\hline \multirow{2}{*}{ Component (\%) } & \multicolumn{2}{|c|}{ Feldspar } & \multicolumn{2}{c|}{ Rock phosphate } \\
\cline { 2 - 5 } & From & To & From & To \\
\hline $\mathrm{SiO}_{2}$ & 68.56 & 70.23 & 10.60 & 12.78 \\
\hline $\mathrm{TiO}_{2}$ & 0.02 & 0.04 & 0.02 & 0.03 \\
\hline $\mathrm{Al}_{2} \mathrm{O}_{3}$ & 13.23 & 16.25 & 0.35 & 0.65 \\
\hline $\mathrm{Fe}_{2} \mathrm{O}_{3}$ & 0.17 & 0.40 & 1.12 & 1.35 \\
\hline $\mathrm{MnO}$ & 0.02 & 0.06 & 0.07 & 0.08 \\
\hline $\mathrm{Mg} \mathrm{O}$ & 0.03 & 0.05 & 0.33 & 0.61 \\
\hline $\mathrm{CaO}$ & 0.26 & 0.47 & 44.12 & 48.63 \\
\hline $\mathrm{Na}_{2} \mathrm{O}$ & 2.25 & 3.69 & 0.18 & 1.12 \\
\hline $\mathrm{K}_{2} \mathrm{O}$ & 6.20 & 8.12 & 0.03 & 0.05 \\
\hline $\mathrm{P}_{2} \mathrm{O}_{5}$ & 0.02 & 0.03 & 20.00 & 22.00 \\
\hline $\mathrm{SO}_{3}(\%)$ & - & - & 0.32 & 1.98 \\
\hline
\end{tabular}

Mineral rock analysis by: Producer Company. 
The previous materials were applied in combination at different proportions $(100,75,50,25$ and $0 \%$ for each) in the presence of nitropeine (a mixture of $\mathrm{N}$-fixing bacteria) at $120 \mathrm{~g} /$ tree, phosphoreine (a mixture of $\mathrm{p}$ solubilizing bacteria) at $25 \mathrm{~g} /$ tree and potasseine (a commercial product that contains $30 \% \mathrm{~K}_{2} \mathrm{O}$ and $\left.8 \% \mathrm{P}_{2} \mathrm{O}_{5}\right)$ at $134 \mathrm{~cm} /$ tree form the following 12 combined treatments:

1.. Control $\left(25 \mathrm{~kg}\right.$ as $\mathrm{FYM}+1.5 \mathrm{~kg}$ as $\mathrm{SO}_{4}(\mathrm{NH})_{2}+1 \mathrm{~kg}$ as $\mathrm{CA} \mathrm{H}_{2} \mathrm{P}_{2} \mathrm{O}_{5}$ and $1 \mathrm{~kg}$ as $\mathrm{k}_{2} \mathrm{SO}_{4} /$ tree)..

2. $100 \%$ Compost $+100 \%$ Feldspar $+100 \%$ Rock-P + Biofertilizers $\left(T_{1}\right)$

3. $100 \%$ Compost $+75 \%$ Feldspar $+75 \%$ Rock-P + Biofertilizers $\left(\mathrm{T}_{2}\right)$

4. $100 \%$ Compost $+50 \%$ Feldspar $+50 \%$ Rock-P + Biofertilizers $\left(T_{3}\right)$

5. $100 \%$ Compost $+25 \%$ Feldspar $+25 \%$ Rock-P + Biofertilizers $\left(\mathrm{T}_{4}\right)$

6. $75 \%$ Compost $+100 \%$ Feldspar $+100 \%$ Rock-P + Biofertilizers $\left(T_{5}\right)$

7. $75 \%$ Compost $+75 \%$ Feldspar $+75 \%$ Rock-P + Biofertilizers $\left(\mathrm{T}_{6}\right)$

8. $75 \%$ Compost $+50 \%$ Feldspar $+50 \%$ Rock- $P+$ Biofertilizers $\left(\mathrm{T}_{7}\right)$

9. $75 \%$ Compost $+25 \%$ Feldspar $+25 \%$ Rock-P + Biofertilizers $\left(\mathrm{T}_{8}\right)$

10. $50 \%$ Compost $+100 \%$ Feldspar $+100 \%$ Rock-P + Biofertilizers $\left(T_{9}\right)$

$11.50 \%$ Compost $+75 \%$ Feldspar $+75 \%$ Rock- $P+$ Biofertilizers $\left(T_{10}\right)$

12. $50 \%$ Compost $+50 \%$ Feldspar $+50 \%$ Rock- $P+$ Biofertilizers $\left(T_{11}\right)$

13. $50 \%$ Compost $+25 \%$ Feldspar $+25 \%$ Rock- $P+$ Biofertilizers $\left(T_{12}\right)$

On September, $1^{\text {st }}$ of each season, the total amount of biofertilizers were mixed thoroughly with that of compost plus the total one of rock phosphate were added to the soil at a depth of $20-25 \mathrm{~cm}$ in circled narrow trenches at $1 \mathrm{~m}$ away around trunk of each tree just before irrigation, and then covered completely with soil. As for feldspar doses, they were splitted into two equal splits, where the first one was applied with compost and biofertilizers on September, $1^{\text {st }}$, while the second one was applied on the first of December. A complete randomized design with three replicates, as each one contained only one tree (Mead et al., 1993) was employed in the three studied seasons.

Data recorded:

At the proper time, data were registered as follows:

* Vegetative and flowering growth:

Shoot length $(\mathrm{cm})$, number of leaves $/ \mathrm{lm}$, leaf area $\left(\mathrm{cm}^{2}\right)$ using planimeter and number of flower buds/lm.

* Fruit characteristics and yield:

Number of fruits/lm, length and diameter of fruit $(\mathrm{cm})$, fruit size $\left(\mathrm{cm}^{3}\right)$, fruit weight $(\mathrm{g})$, flesh thickness $(\mathrm{cm})$, fruit firmness $\left(\mathrm{g} / \mathrm{cm}^{2}\right)$ and yield $(\mathrm{kg} / \mathrm{tree})$.

* Fruit chemical properties:

- Total soluble solids (TSS \%) were determined by a bbe refractometer using the method of A.O.A.C. (1995).

- Total acidity (\%) was measured by titration method described by A.O.A.C. (1975).

- TSS/acidity was calculated as a ratio.

- Vitamin C (ascorbic acid) was evaluated by the method of Horwitz (1970) as $\mathrm{mg} / 100 \mathrm{~g}$ fruit flesh.

- Leaf content of minerals. 
In dry leaf samples taken from the middle part of the shoot, the percentages of nitrogen (A.O.A.C., 1995), phosphorus (Wide et al., 1985), potassium (by flame photometer set as indicated by Jackson, (1973) and calcium and magnesium (Dewis and Freitas, 1970) were assessed.

* Statistical analysis:

Data were then tabulated and statistically analyzed according to SAS Institute program (1994) using Duncan's Multiple Range Test (Duncan, 1955) for elucidating the significancy between the means of various treatments.

\section{RESULTS AND DISCUSSION}

\section{Effect of fertilization treatments on:}

\section{1- Vegetative growth and flower bud number:}

It is obvious from data recorded in Table (4) that the means of shoot length $(\mathrm{cm})$, No. of leaves/m and leaf area $\left(\mathrm{cm}^{2}\right)$ were increased over those of control by some fertilization combined treatments used in the present study, while other combinations gave means slightly higher or lower than those of control with non-significant differences between them in the three growing seasons. In general, the superiority in the three seasons was for the combination of $75 \%$ compost $+100 \%$ feldspar $+100 \%$ rock phosphate + biofertlilizer mixture which gave the highest values relative to other combinations in most cases of the 3 seasons. A similar trend was also obtained concerning the number of flower buds $/ \mathrm{m}$, as the previously mentioned super combination also scored the utmost high means over control and other used combinations in the 3 studied seasons giving the highest No. flower buds $/ \mathrm{m}$.

This may be ascribed to the synergistic effect of compost, mineral rocks and biofertilizers as indicated before in case of irrigated guava cv. "Etmani" (Part, I). In this connection, Dwivedi et al., (2012) mentioned that increasing "Red Flashed" guava growth may be attributed to increase in level of readily available N, P, K and other nutrients in the presence of organic manure which often enhanced growth mechanism in plants. Increasing soil chemical and physical properties that were induced by organic manure application may be a direct reason for improving growth (Muhammad et al., 2000). Glick (2004) suggested that plant growth promoting rhizobacteria (PGPR) could benefit plants growth and yield through: biological $\mathrm{N}$-fixation, phosphate solubilization, the production of siderophors, the production of secondary metabolites such as antibiotic, hydrogen, cyanid and plant hormones (i.e., IAA), releasing of $K$ and antagonism to soil borne root pathogens. 
J. Plant Production, Mansoura Univ., Vol. 6 (7), July, 2014

$4-$

1121 
The previous results are in great accordance with those revealed on guava cvs. by Mikhail et al., (2007), El-Sharkawy and Osman (2009), Mitra et al., (2010), Devi et al., (2012) and Yadav $t$ al., (2013) whom reported that application of various organic substances increased plant spread and No. branches/plant. On winter season crop of guava cv. Sardar, Dashora et al., (2007) found that the minimum days taken to initiation of flowering and maximum No. of flowers/shoot were recorded by vermicompost $(10 \mathrm{~kg} / \mathrm{plant})$ + $50 \%$ recommended dose of NPK + P-solubilizing bacteria (20 g/plant) treatment.

2- Yield and fruit characteristics:

From data averaged in Table (5), it can be summarized that $75 \%$ compost $+100 \%$ feldspar $+100 \%$ rock phosphate + biofertilizer mixture combined treatment mostly induced the best improvement in No. of fruits $/ \mathrm{m}$, fruit weight $(\mathrm{g})$, yield $(\mathrm{kg} / \mathrm{tree})$, fruit length $(\mathrm{cm})$, diameter $(\mathrm{cm})$ and volume $\left(\mathrm{cm}^{3}\right)$, as well as flesh thickness $(\mathrm{cm})$ where such combination elevated the means of these parameters to the utmost high values in comparison to control and other combinations, with few exceptions in the 3 studied seasons.

This may be comprehensible because this combination gave the best vegetative and flowering growth throughout the three growing seasons as indicated before in Table (4), and that was usefully, reflected on increasing yield and improving fruit characteristics. In this regard, Dwivedi et al., (2012) mentioned that application of biofertilizers in the presence of organic manure was more effective in enhancing fruit growth parameters due to the increased availability of nutrients which might have reflected the increase in fruit weight, length and breadth.

Similar results were also attained by El-Shobaky (2007), Bashir et al., (2009), El-Sharkawy and Osman (2009), El-Baz et al., (2011) and Dwivedi et al., (2012) on winter crop of guava. Furthermore, Devi et al., (2012) concluded that application of FYM at $26 \mathrm{~kg} /$ tree/y + azotobacter (100 g/tree) + P-solubilizer (100 g/tree) + K-mobilizer (100 g/tree) in two splits (January and August) is the economically profitable treatment for cultivation of guava cv. "Sardar". 
Table (5): Effect of fertilization treatments on yield and fruit characteristics of (Psidium guajava L.) "Etmani" cv. tree under fasting system during 2011/12, 2012/13 and 2013/14 seasons.

\begin{tabular}{|c|c|c|c|c|c|c|c|}
\hline Treatments & $\begin{array}{c}\text { No. } \\
\text { fruits } \\
\text { per Im }\end{array}$ & $\begin{array}{c}\text { Fruit } \\
\text { weight } \\
\text { (g) }\end{array}$ & $\begin{array}{c}\text { Yield } \\
\text { (kg/tree) }\end{array}$ & \begin{tabular}{|c|}
$\begin{array}{c}\text { Fruit } \\
\text { length } \\
(\mathrm{cm})\end{array}$ \\
\end{tabular} & $\begin{array}{c}\text { Fruit } \\
\text { diameter } \\
(\mathrm{cm})\end{array}$ & $\begin{array}{c}\text { Fruit } \\
\text { volume } \\
\left(\mathrm{cm}^{3}\right)\end{array}$ & \begin{tabular}{|c|} 
Flesh \\
thickness \\
(cm)
\end{tabular} \\
\hline & \multicolumn{7}{|c|}{ First season: $2011 / 2012$} \\
\hline Control & $17.78 \mathrm{~g}$ & $46.55 c$ & $24.67 f$ & $4.57 f$ & $4.03 \mathrm{e}$ & $46.00 \mathrm{c}$ & $1.37 \mathrm{c}$ \\
\hline $100 \% C+100 \% K+100 \% P+$ Bio-F. & $24.61 \mathrm{e}$ & $48.35 b$ & 30.00de & 5.03de & $4.63 a-c$ & $46.67 \mathrm{c}$ & $1.33 c$ \\
\hline $100 \% \mathrm{C}+75 \% \mathrm{~K}+75 \% \mathrm{P}+$ Bio-F. & $29.05 b c$ & $51.55 a$ & $39.00 \mathrm{ab}$ & $5.43 b-d$ & $4.40 \mathrm{~b}-\mathrm{e}$ & $51.00 a b$ & $1.43 \mathrm{bc}$ \\
\hline $100 \% \mathrm{C}+50 \% \mathrm{~K}+50 \% \mathrm{P}+$ Bio-F. & $26.12 \mathrm{de}$ & $51.52 a$ & $35.33 \mathrm{bc}$ & $5.23 c-e$ & $4.17 \mathrm{de}$ & $51.67 a$ & $1.50 \mathrm{a}-\mathrm{c}$ \\
\hline $100 \% C+25 \% K+25 \% P+$ Bio-F. & $27.99 b-d$ & $50.58 a$ & 28.00ef & $5.33 b-d$ & $4.47 a-d$ & $50.00 \mathrm{~b}$ & $1.37 \mathrm{c}$ \\
\hline $75 \% \mathrm{C}+100 \% \mathrm{~K}+100 \% \mathrm{P}+$ Bio-F. & $31.43 a$ & $52.30 \mathrm{a}$ & $42.33 a$ & $5.77 a b$ & $4.43 a-d$ & $51.33 a$ & $1.67 \mathrm{a}$ \\
\hline $75 \% \mathrm{C}+75 \% \mathrm{~K}+75 \% \mathrm{P}+$ Bio-F. & $27.27 \mathrm{~cd}$ & $51.53 a$ & 29.67de & $5.77 a b$ & $4.80 \mathrm{a}$ & $51.00 \mathrm{ab}$ & $1.43 \mathrm{bc}$ \\
\hline $75 \% \mathrm{C}+50 \% \mathrm{~K}+50 \% \mathrm{P}+\mathrm{Bio}-\mathrm{F}$. & $22.24 f$ & $50.92 a$ & 30.00de & $5.67 a-c$ & $4.77 a b$ & $50.67 a b$ & $1.50 \mathrm{a}-\mathrm{c}$ \\
\hline $75 \% C+25 \% \mathrm{~K}+25 \% \mathrm{P}+$ Bio-F. & $25.13 e$ & $51.38 \mathrm{a}$ & $33.00 \mathrm{~cd}$ & $5.33 b-d$ & $4.60 a-c$ & $51.33 a$ & $1.50 \mathrm{a}-\mathrm{c}$ \\
\hline $50 \% \mathrm{C}+100 \% \mathrm{~K}+100 \% \mathrm{P}+\mathrm{Bio}-\mathrm{F}$. & $25.95 \mathrm{de}$ & $50.57 a$ & $33.33 \mathrm{~cd}$ & $5.70 a-c$ & $4.33 c-e$ & $50.67 a b$ & $1.67 a$ \\
\hline $50 \% \mathrm{C}+75 \% \mathrm{~K}+75 \% \mathrm{P}+$ Bio-F. & $29.71 \mathrm{ab}$ & $51.18 \mathrm{a}$ & $33.00 \mathrm{~cd}$ & $4.83 \mathrm{ef}$ & $4.17 \mathrm{de}$ & $50.67 a b$ & $1.67 a$ \\
\hline $50 \% \mathrm{C}+50 \% \mathrm{~K}+50 \% \mathrm{P}+$ Bio-F. & $24.89 \mathrm{e}$ & $50.90 a$ & $35.67 \mathrm{bc}$ & $5.17 \mathrm{de}$ & $4.43 a-d$ & $51.33 a$ & $.47 \mathrm{bc}$ \\
\hline \multirow[t]{2}{*}{$50 \% \mathrm{C}+25 \% \mathrm{~K}+25 \% \mathrm{P}+$ Bio-F. } & $26.46 \mathrm{de}$ & $50.83 a$ & $33.33 \mathrm{bc}$ & $6.03 a$ & $4.27 c-e$ & $50.67 a b$ & $0 \mathrm{ab}$ \\
\hline & \multicolumn{7}{|c|}{ Second season: $2012 / 13$} \\
\hline Control & $18.89 f$ & $50.95 f$ & $29.00 \mathrm{e}$ & $4.93 \mathrm{~b}-\mathrm{e}$ & $4.10 \mathrm{bc}$ & $49.67 e$ & $1.57 c-f$ \\
\hline $100 \% C+100 \% \mathrm{~K}+100 \% \mathrm{P}+$ Bio-F. & $27.11 d$ & $51.43 \mathrm{ef}$ & $34.33 b$ & $5.17 b-d$ & $4.27 \mathrm{bc}$ & $50.67 d$ & $1.50 \mathrm{ef}$ \\
\hline $100 \% \mathrm{C}+75 \% \mathrm{~K}+75 \% \mathrm{P}+$ Bio-F. & $29.91 \mathrm{ab}$ & $53.85 a$ & $42.33 b$ & $5.17 b-d$ & $4.23 \mathrm{bc}$ & $53.33 a$ & $1.67 \mathrm{~b}-\mathrm{d}$ \\
\hline $100 \% \mathrm{C}+50 \% \mathrm{~K}+50 \% \mathrm{P}+$ Bio-F. & $29.58 b$ & $53.52 \mathrm{ab}$ & $39.00 b-d$ & $4.80 c-e$ & $4.10 \mathrm{bc}$ & $52.33 \mathrm{bc}$ & $1.53 d-f$ \\
\hline $100 \% C+25 \% K+25 \% P+$ Bio-F. & $45 b-d$ & $52.56 a-e$ & $7 e$ & $4.83 \mathrm{c}-\mathrm{e}$ & $\mathrm{bc}$ & $52.00 \mathrm{bc}$ & $50 \mathrm{ef}$ \\
\hline $75 \% \mathrm{C}+100 \% \mathrm{~K}+100 \% \mathrm{P}+\mathrm{Bio}-\mathrm{F}$. & $31.47 a$ & $53.07 a-c$ & $46.33 a$ & $5.40 \mathrm{~b}$ & $4.97 a$ & $53.33 a$ & $83 a$ \\
\hline $75 \% \mathrm{C}+75 \% \mathrm{~K}+75 \% \mathrm{P}+\mathrm{Bio}-\mathrm{F}$. & $29.32 b c$ & $52.17 c-f$ & 35.33de & $5.27 \mathrm{bc}$ & $4.53 a-c$ & $51.33 \mathrm{bc}$ & $1.50 \mathrm{ef}$ \\
\hline $75 \% \mathrm{C}+50 \% \mathrm{~K}+50 \% \mathrm{P}+$ Bio-F. & $24.14 \mathrm{e}$ & $52.68 a-e$ & 35.00de & $4.83 c-e$ & $4.10 \mathrm{bc}$ & $52.33 \mathrm{bc}$ & $1.63 \mathrm{~b}-\mathrm{e}$ \\
\hline $75 \% C+25 \% K+25 \% P+$ Bio-F. & $27.43 d$ & $52.85 a-d$ & $36.00 c-e$ & 4.70de & $4.77 a b$ & $52.67 a b$ & $1.47 f$ \\
\hline $50 \% \mathrm{C}+100 \% \mathrm{~K}+100 \% \mathrm{P}+$ Bio-F. & $25.18 \mathrm{e}$ & $52.37 b-e$ & $37.00 c-e$ & $5.10 b-d$ & $3 c$ & $52.67 \mathrm{ab}$ & $1.77 a b$ \\
\hline $50 \% \mathrm{C}+75 \% \mathrm{~K}+75 \% \mathrm{P}+\mathrm{Bio}-\mathrm{F}$. & $28.62 b-d$ & $52.58 \mathrm{a}-\mathrm{e}$ & $42.00 \mathrm{~b}$ & $4.57 \mathrm{e}$ & $3.93 c$ & $52.33 \mathrm{bc}$ & $1.73 a b$ \\
\hline $50 \% \mathrm{C}+50 \% \mathrm{~K}+50 \% \mathrm{P}+\mathrm{Bio}-\mathrm{F}$. & $25.29 \mathrm{e}$ & $52.32 b-e$ & $40.00 \mathrm{bc}$ & $5.33 \mathrm{bc}$ & $4.63 a-c$ & $52.33 \mathrm{bc}$ & $1.70 \mathrm{a}-\mathrm{c}$ \\
\hline \multirow[t]{2}{*}{$50 \% \mathrm{C}+25 \% \mathrm{~K}+25 \% \mathrm{P}+\mathrm{Bio}-\mathrm{F}}$. & $27.70 \mathrm{~cd}$ & $51.62 d-f$ & $36.00 c-e$ & $5.97 a$ & $4.30 \mathrm{bc}$ & $50.67 d$ & $1.67 \mathrm{~b}-\mathrm{d}$ \\
\hline & \multicolumn{7}{|c|}{ Third season: $2013 / 14$} \\
\hline Control & $22.93 \mathrm{~g}$ & $51.56 \mathrm{~d}$ & $32.00 \mathrm{~d}$ & $6.00 \mathrm{~b}$ & $3.80 \mathrm{bc}$ & $50.00 \mathrm{~d}$ & $1.57 \mathrm{de}$ \\
\hline $100 \% \mathrm{C}+100 \% \mathrm{~K}+100 \% \mathrm{P}+\mathrm{Bio}-\mathrm{F}$. & $28.82 f$ & $51.66 \mathrm{~d}$ & $40.33 c$ & $6.27 a b$ & $4.13 a-c$ & $50.67 d$ & $1.50 \mathrm{e}$ \\
\hline $100 \% \mathrm{C}+75 \% \mathrm{~K}+75 \% \mathrm{P}+$ Bio-F. & $34.14 b$ & $57.08 \mathrm{a}$ & $50.33 \mathrm{~b}$ & $6.53 \mathrm{ab}$ & $3.67 \mathrm{c}$ & $55.33 a$ & $1.77 a b$ \\
\hline $100 \% \mathrm{C}+50 \% \mathrm{~K}+50 \% \mathrm{P}+$ Bio-F. & $30.87 \mathrm{c}-\mathrm{e}$ & $55.27 \mathrm{~b}$ & $46.00 \mathrm{bc}$ & $6.00 \mathrm{~b}$ & $4.07 a-c$ & $55.00 a$ & $1.63 b-d$ \\
\hline $100 \% C+25 \% K+25 \% P+$ Bio-F. & $32.33 \mathrm{bc}$ & $53.15 \mathrm{~cd}$ & $40.33 c$ & $6.60 a$ & $3.67 c$ & $53.00 \mathrm{~b}$ & $1.57 \mathrm{de}$ \\
\hline $75 \% \mathrm{C}+100 \% \mathrm{~K}+100 \% \mathrm{P}+\mathrm{Bio}-\mathrm{F}$. & $35.99 a$ & $55.13 b$ & $56.33 a$ & $6.37 a b$ & $4.53 a$ & $54.67 a$ & $1.87 a$ \\
\hline $75 \% \mathrm{C}+75 \% \mathrm{~K}+75 \% \mathrm{P}+\mathrm{Bio}-\mathrm{F}$. & $32.81 \mathrm{bc}$ & $53.79 \mathrm{bc}$ & $42.00 \mathrm{c}$ & $6.20 \mathrm{ab}$ & $3.97 \mathrm{bc}$ & $53.00 \mathrm{~b}$ & $1.73 b$ \\
\hline $75 \% \mathrm{C}+50 \% \mathrm{~K}+50 \% \mathrm{P}+\mathrm{Bio}-\mathrm{F}$. & 29.27ef & $52.59 \mathrm{~cd}$ & $41.00 \mathrm{c}$ & 6.37ab & $3.70 \mathrm{c}$ & $52.33 \mathrm{bc}$ & $1.63 b-d$ \\
\hline $75 \% C+25 \% K+25 \% P+$ Bio-F. & $32.01 \mathrm{~cd}$ & $52.59 \mathrm{~cd}$ & $42.33 \mathrm{c}$ & $5.97 \mathrm{~b}$ & $3.90 \mathrm{bc}$ & $52.00 \mathrm{c}$ & $1.77 a b$ \\
\hline $50 \% \mathrm{C}+100 \% \mathrm{~K}+100 \% \mathrm{P}+$ Bio-F. & $30.11 d-f$ & $53.18 \mathrm{~cd}$ & $41.67 \mathrm{c}$ & $6.30 a b$ & $4.27 a b$ & $52.00 \mathrm{c}$ & $1.77 a b$ \\
\hline $50 \% \mathrm{C}+75 \% \mathrm{~K}+75 \% \mathrm{P}+\mathrm{Bio}-\mathrm{F}$. & $32.68 \mathrm{bc}$ & $53.30 \mathrm{~cd}$ & $45.00 \mathrm{bc}$ & $6.23 \mathrm{ab}$ & $4.07 a-c$ & $52.67 \mathrm{bc}$ & $1.73 b$ \\
\hline $50 \% \mathrm{C}+50 \% \mathrm{~K}+50 \% \mathrm{P}+$ Bio-F. & 29.20ef & $52.91 \mathrm{~cd}$ & $45.33 \mathrm{bc}$ & $5.97 \mathrm{~b}$ & $3.87 \mathrm{bc}$ & $52.67 \mathrm{bc}$ & $1.70 \mathrm{bc}$ \\
\hline $50 \% C+25 \% K+25 \% P+$ Bio-F. & $30.23 d-f$ & $53.27 \mathrm{~cd}$ & $40.00 c$ & $6.30 \mathrm{ab}$ & $3.80 \mathrm{bc}$ & $52.67 \mathrm{bc}$ & $1.60 \mathrm{~b}-\mathrm{d}$ \\
\hline
\end{tabular}

* C: Compost; K: Feldspar; P: Rock phosphate, Bio-F.: Nitrobeine, Phosphorene, Potasseine and Im: Longitudinal meter.

* Means within a column having the same letters are not significantly different according to Duncan`s Multiple Range Test at $5 \%$ level. 


\section{3- Chemical composition and firmness of fruits:}

Data in Table (6) show that mean of TSS \% was increased significantly only in the first season to $11.23 \%$ by $100 \%$ compost $+25 \%$ feldspar $+25 \%$ rock phosphate + biofertilizer mixture combined treatment against $10.57 \%$ for control, while other combinations slightly improved such parameter with non-significant differences among them in most cases. In the second and third seasons, however, all fertilization treatments caused a slight improvement in this trait also, without significant differences in between. Likely the percent of acidity went to a similar behaviour, as the differences between treatments and control were nonsignificant in the 3 studied seasons, but the least percent of acidity was recorded in the $1^{\text {st }}$ and $2^{\text {nd }}$ seasons by fertilizing with $100 \%$ compost $+25 \%$ feldspar +25 rock phosphate + biofertilizer mixture combined treatment, whereas in the $3^{\text {rd }}$ one, that was attained by $75 \%$ compost $+100 \%$ feldspar $+100 \%$ rock phosphate + biofertilizer mixture combined one, which directly followed by a combination reduced acidity to the minimal values in the $1^{\text {st }}$ and $2^{\text {nd }}$ seasons that mentioned above. Hence, the highest ratio of TSS/acidity was recorded in the $1^{\text {st }}$ and $2^{\text {nd }}$ seasons by combining between $100 \%$ compost, $25 \%$ feldspar, $25 \%$ rock phosphate and mixture of biofertilizers, while in the $3^{\text {rd }}$ one, that was achieved by combining between $75 \%$ compost, $100 \%$ feldspar, $100 \%$ rock phosphate and biofertilizer mixture. The other fertilization treatments slightly improved such ratio without significant differences with control in the 3 growing seasons.

In the matter of vitamin $\mathrm{C}$ content ( $\mathrm{mg} / 100 \mathrm{~g}$ fresh flesh) and fruit firmness $\left(\mathrm{g} / \mathrm{cm}^{2}\right)$, data in Table (6) clear that means of these two measurements reached the maximum in the first season by a combination of $75 \%$ compost $+75 \%$ feldspar $+75 \%$ rock phosphate + biofertilizer mixture, while in the second season that was established by a combination of $100 \%$ compost $+25 \%$ feldspar $+25 \%$ rock phosphate + biofertilizer mixture. In the $3^{\text {rd }}$ season, $50 \%$ compost $+100 \%$ feldspar $+100 \%$ rock phosphate + biofertilizer mixture combined treatment gave the highest content of vitamin $\mathrm{C}$ over control and other combinations, but a combined one comparing $100 \%$ compost $+100 \%$ feldspar $+100 \%$ rock phosphate + biofertilizer mixture registered the highest average of fruit firmness at all.

These gains may be interpretted and discussed as done before in case of vegetative growth, yield and fruit characteristics. Analogous findings were also detected on winter guava by Mikhail et al., (2007), Dashora et al., (2007), Bashir et al., (2009) and Dwivedi et al., (2012) who suggested that improving physical and chemical characteristics of guava fruits may be attributed to the better vegetative growth of the fertilized plants which resulted in higher quantities of photosynthates (starch, carbohydrates, ... etc) and their translocation to the fruits, thus improving the various quality parameters. Application of P-solubilizers significantly influenced vitamin $\mathrm{C}$ content in guava over the control during winter season. When biofertilizers were grouped together, P-solubilizers were found to have more beneficial influence on fruit physico-chemical parameters of "Red Fleshed" guava than the $\mathrm{N}$-fixers (Dey et al., 2005). This could perhaps be due to better availability of phosphorus to the plant which improves the quality characteristics of the fruits. Beneficial effect of organic compost is ascribed to the presence of macro-and micro-nutrients and vital plant promoting substances in organic compost (Singh, 2007). 
Table (6): Effect of fertilization treatments on chemical composition and firmness of (Psidium guajava) L. "Etmani" cv. fruits under fasting system during 2011/12, 2012/13 and 2013/14 seasons.

\begin{tabular}{|c|c|c|c|c|c|}
\hline Treatments & $\begin{array}{l}\text { TSS } \\
\text { (\%) }\end{array}$ & $\begin{array}{c}\text { Acidity } \\
(\%)\end{array}$ & $\begin{array}{l}\text { TSS/ } \\
\text { acidity } \\
\text { ratio }\end{array}$ & $\begin{array}{c}\text { Vitamin C } \\
\text { (mg/100 g } \\
\text { f.f.) }\end{array}$ & $\begin{array}{c}\text { Fruit } \\
\text { Firmness } \\
\left(\mathrm{g} / \mathrm{cm}^{2}\right)\end{array}$ \\
\hline \multicolumn{6}{|c|}{ First season: $2011 / 12$} \\
\hline Control & $10.57 \mathrm{~d}$ & $0.400 a$ & $28.37 a-d$ & $42.73 d$ & $113.0 \mathrm{~g}$ \\
\hline $100 \% \mathrm{C}+100 \% \mathrm{~K}+100 \% \mathrm{P}+$ Bio-F. & $10.87 a-d$ & $0.400 a$ & $28.37 a-d$ & $43.70 a-c$ & $115.7 \mathrm{fg}$ \\
\hline $100 \% \mathrm{C}+75 \% \mathrm{~K}+75 \% \mathrm{P}+$ Bio-F. & $10.93 a-d$ & $0.367 a$ & $30.44 a-c$ & $44.20 a b$ & $121.3 d-f$ \\
\hline $100 \% \mathrm{C}+50 \% \mathrm{~K}+50 \% \mathrm{P}+$ Bio-F. & $10.87 a-d$ & $0.433 a$ & $25.38 \mathrm{~b}-\mathrm{d}$ & $43.43 b-d$ & $132.0 \mathrm{~b}$ \\
\hline $100 \% C+25 \% \mathrm{~K}+25 \% \mathrm{P}+$ Bio-F. & $11.23 a$ & $0.333 a$ & $33.75 a$ & $43.80 \mathrm{a}-\mathrm{c}$ & $125.0 \mathrm{c}-\mathrm{e}$ \\
\hline $75 \% C+100 \% \mathrm{~K}+100 \% P+$ Bio-F. & $10.83 a-c$ & $0.467 a$ & $22.92 d$ & $44.20 \mathrm{ab}$ & $131.0 \mathrm{bc}$ \\
\hline $75 \% C+75 \% K+75 \% P+$ Bio-F. & $11.10 a b$ & $0.400 a$ & $27.75 b-d$ & $44.60 \mathrm{a}$ & $139.7 a$ \\
\hline $75 \% C+50 \% K+50 \% P+$ Bio-F. & $11.00 \mathrm{a}-\mathrm{c}$ & $0.433 a$ & $25.65 b-d$ & $44.07 a-c$ & 119.7ef \\
\hline $75 \% C+25 \% K+25 \% P+$ Bio-F. & $10.67 \mathrm{~cd}$ & $0.433 a$ & $24.95 \mathrm{~cd}$ & $43.13 \mathrm{~cd}$ & 121.3d-f \\
\hline $50 \% C+100 \% \mathrm{~K}+100 \% \mathrm{P}+$ Bio-F. & $11.00 \mathrm{a}-\mathrm{c}$ & $0.367 a$ & $30.58 \mathrm{a}-\mathrm{c}$ & $43.90 \mathrm{a}-\mathrm{c}$ & $124.7 \mathrm{c}-\mathrm{e}$ \\
\hline $50 \% \mathrm{C}+75 \% \mathrm{~K}+75 \% \mathrm{P}+$ Bio-F. & $10.80 \mathrm{~b}-\mathrm{d}$ & $0.433 a$ & $25.17 \mathrm{~b}-\mathrm{d}$ & $43.57 \mathrm{~b}-\mathrm{d}$ & $126.7 b-d$ \\
\hline $50 \% \mathrm{C}+50 \% \mathrm{~K}+50 \% \mathrm{P}+$ Bio-F. & $10.70 \mathrm{~cd}$ & $0.400 \mathrm{a}$ & $27.93 a-d$ & $44.07 a-c$ & $121.7 d-f$ \\
\hline $50 \% C+25 \% \mathrm{~K}+25 \% \mathrm{P}+$ Bio-F. & $11.03 a-c$ & $0.367 a$ & $31.08 \mathrm{bc}$ & $43.70 a-c$ & $130.7 \mathrm{bc}$ \\
\hline \multicolumn{6}{|c|}{ Second season: $2012 / 13$} \\
\hline Control & $10.67 a$ & $0.433 a$ & $24.85 \mathrm{c}$ & $42.87 \mathrm{~b}$ & $110.0 \mathrm{e}$ \\
\hline $0 \% \mathrm{P}+\mathrm{Bio}-\mathrm{F}$. & $10.93 a-d$ & $0.433 a$ & $25.52 \mathrm{c}$ & $7 a$ & $136.7 a$ \\
\hline $100 \% \mathrm{C}+75 \% \mathrm{~K}+75 \% \mathrm{P}+$ Bio-F. & $10.80 \mathrm{a}$ & $0.333 a$ & $33.14 a b$ & $3 b$ & $119.7 d$ \\
\hline $100 \% C+50 \%$ & $10.90 \mathrm{a}$ & $0.400 \mathrm{a}$ & $28.44 b c$ & $44.40 \mathrm{a}$ & $128.7 \mathrm{bc}$ \\
\hline $100 \% C+25 \%$ & $10.93 a-d$ & $0.300 \mathrm{a}$ & $36.44 a$ & $44.33 a$ & $138.3 a$ \\
\hline $75 \% C+100^{\circ}$ & $10.90 \mathrm{a}$ & $0.333 a$ & $33.31 a b$ & 43.80ab & $121.3 d$ \\
\hline $75 \% \mathrm{C}+75 \% \mathrm{~K}+75 \% \mathrm{P}+$ Bio-F. & $11.10 \mathrm{a}$ & $0.400 a$ & $30.83 b$ & $43.87 a b$ & 134.0ab \\
\hline $75 \% C+50 \% K+50 \% P+$ Bio-F. & $10.97 a$ & $0.333 a$ & $33.56 a b$ & 43.70ab & $124.7 \mathrm{~cd}$ \\
\hline $75 \% C+25 \% K+25 \% P+$ Bio-F. & $10.73 a$ & $0.333 a$ & $32.78 a b$ & $43.53 a b$ & 133.3ab \\
\hline $50 \% C+100 \% \mathrm{~K}+100 \% P+$ Bio-F. & $10.90 \mathrm{a}$ & $0.400 \mathrm{a}$ & $28.50 \mathrm{bc}$ & 43.77ab & 133.0ab \\
\hline $50 \% \mathrm{C}+75 \% \mathrm{~K}+75 \% \mathrm{P}+$ Bio-F. & $10.67 a$ & $0.433 a$ & $24.95 \mathrm{c}$ & $3 a$ & $129.0 \mathrm{bc}$ \\
\hline $50 \% \mathrm{C}+50 \% \mathrm{~K}+50 \% \mathrm{P}+$ Bio-F. & $11.00 \mathrm{a}$ & $0.433 a$ & $25.65 \mathrm{c}$ & $44.23 a$ & $119.0 \mathrm{~d}$ \\
\hline $50 \% \mathrm{C}+25 \% \mathrm{~K}+25 \% \mathrm{P}+$ Bio-F. & $10.83 a$ & $0.433 a$ & $25.28 \mathrm{c}$ & $44.23 a$ & $130.3 \mathrm{bc}$ \\
\hline \multicolumn{6}{|c|}{ Third season: $2013 / 14$} \\
\hline Control & $9.43 a$ & $0.400 a-c$ & $24.49 c-e$ & $42.60 \mathrm{e}$ & $121.0 f$ \\
\hline $100 \% \mathrm{C}+100 \% \mathrm{~K}+100 \% \mathrm{P}+\mathrm{Bio}-\mathrm{F}$. & $9.33 a$ & $0.367 a-c$ & $26.03 b-e$ & $43.20 \mathrm{ab}$ & $156.3 a$ \\
\hline $100 \% \mathrm{C}+75 \% \mathrm{~K}+75 \% \mathrm{P}+$ Bio-F. & 9.90a & $0.367 a-c$ & $27.47 a-c$ & $44.03 a-c$ & $136.0 \mathrm{~b}-\mathrm{e}$ \\
\hline $100 \% \mathrm{C}+50 \% \mathrm{~K}+50 \% \mathrm{P}+$ Bio-F. & $9.47 a$ & $0.367 a-c$ & $26.14 b-e$ & 42.70de & $131.0 \mathrm{e}$ \\
\hline $100 \% C+25 \% K+25 \% P+$ Bio-F. & $9.60 \mathrm{a}$ & $0.333 \mathrm{bc}$ & $30.28 a b$ & $43.80 a-c$ & $131.0 \mathrm{e}$ \\
\hline $75 \% C+100 \% \mathrm{~K}+100 \% \mathrm{P}+$ Bio-F. & $9.93 a$ & $0.300 \mathrm{c}$ & $32.00 \mathrm{a}$ & $44.07 a-c$ & $134.0 \mathrm{c}-\mathrm{e}$ \\
\hline $75 \% \mathrm{C}+75 \% \mathrm{~K}+75 \% \mathrm{P}+$ Bio-F. & $9.73 a$ & $0.333 \mathrm{bc}$ & $29.72 a b$ & $43.57 b-d$ & $140.0 \mathrm{bc}$ \\
\hline $75 \% \mathrm{C}+50 \% \mathrm{~K}+50 \% \mathrm{P}+$ Bio-F. & $9.43 a$ & $0.433 a b$ & $22.02 \mathrm{de}$ & $43.13 c-e$ & $140.7 \mathrm{~b}$ \\
\hline $75 \% C+25 \% K+25 \% P+$ Bio-F. & $9.73 a$ & $0.400 \mathrm{a}-\mathrm{c}$ & $25.39 b-e$ & $43.57 b-d$ & 133.0de \\
\hline $50 \% \mathrm{C}+100 \% \mathrm{~K}+100 \% \mathrm{P}+\mathrm{Bio}-\mathrm{F}$. & $9.47 a$ & $0.433 a b$ & $22.03 \mathrm{de}$ & $44.70 \mathrm{a}$ & $137.7 b-d$ \\
\hline $50 \% \mathrm{C}+75 \% \mathrm{~K}+75 \% \mathrm{P}+\mathrm{Bio}-\mathrm{F}$. & $9.63 a$ & $0.367 a-c$ & $26.56 \mathrm{~b}-\mathrm{d}$ & $43.47 \mathrm{~b}-\mathrm{e}$ & $138.0 \mathrm{~b}-\mathrm{d}$ \\
\hline $50 \% \mathrm{C}+50 \% \mathrm{~K}+50 \% \mathrm{P}+$ Bio-F. & $9.83 a$ & $0.367 a-c$ & 27.31a-c & 43.30b-e & $135.7 b-e$ \\
\hline $50 \% \mathrm{C}+25 \% \mathrm{~K}+25 \% \mathrm{P}+$ Bio-F. & $9.90 a$ & $0.467 a$ & $21.48 \mathrm{e}$ & $44.07 a-c$ & $137.3 b-d$ \\
\hline
\end{tabular}

C: Compost; K: Feldspar; P: Rock phosphate, and Bio-F.: Nitrobeine, Phosphorene and Potasseine..

* Means within a column having the same letters are not significantly different according to Duncan's Multiple Range Test at $5 \%$ level. 


\section{4- Mineral content of the leaves:}

According to the fluctuated data listed in Table (7), it can be concluded that the percentages of $\mathrm{N}, \mathrm{P}, \mathrm{K}, \mathrm{Ca}$ and $\mathrm{Mg}$ in the leaves of fertilized trees were generally improved over control ones, with few exceptions in the three studied seasons. No treatment among the fertilization ones used in this study had the upper hand in improving minerals content. Thus, it is difficult to recommended one of them over the others.

Improvement mineral content in the leaves of treated plants may indicate the role of biofertilizers grouped with organic compost and mineral rocks in solubilizing most of the major and minor elements are thought to be present in such organic manure and rocks in unavailable form and converted them into available ones (Muhammad, 2000). These results, however go in line with those obtained on various guava cvs. by Mitra et al., (2010), Wali et al., (2011), Barne et al., (2012), Hernandez et al., (2013), Nunes et al., (2014) and Ram et al., (2014) whom revealed that maximum leaf N, P, K, Ca and Zn in guava cv. Allahabad Safeda was noticed at application of Ficus bengalensis leaves compost ( $250 \mathrm{~g} /$ tree $)+5 \%$ Amritpani + organic mulching, $\mathrm{Mg}$ at application of vermicompost (30 kg/tree) + Azospirillum (250 g/tree) + PSB (50 g/tree) and $\mathrm{Cu}$ and $\mathrm{Mn}$ were recorded with FYM (30 kg/tree) as compared to control.

From the aforestated findings, it is clear that fertilizing winter crop of guava cv. "Etmani" with $75 \%$ of recommended compost dose (30 kg/tree) $+100 \%$ of recommended feldspar dose $(1.2 \mathrm{~kg} / \mathrm{tree})+100 \%$ of recommended rock phosphate dose $(1.3 \mathrm{~kg} /$ tree $)$ plus the used biofertilizers mixture may be one of the best and economic way for organic production of cv. "Etmani" guava in winter under Qalubia governorate conditions. 
Table (7): Effect of fertilization treatments on mineral content of (Psidium guajava L.) "Etmani" cv. leaves under fasting system during 2011/12, 2012/13 and 2013/14 seasons.

\begin{tabular}{|c|c|c|c|c|c|}
\hline Treatments & $\mathbf{N}(\%)$ & $\mathbf{P}(\%)$ & $\mathrm{K}(\%)$ & $\mathrm{Ca}(\%)$ & $\operatorname{Mg}(\%)$ \\
\hline & \multicolumn{5}{|c|}{ First season: $2011 / 12$} \\
\hline Control & $1.593 \mathrm{c}$ & $0.107 \mathrm{j}$ & $1.175 \mathrm{~g}$ & $1.755 f$ & $0.386 \mathrm{j}$ \\
\hline $100 \% \mathrm{C}+100 \% \mathrm{~K}+100 \% \mathrm{P}+$ Bio-F. & $1.847 \mathrm{~b}$ & 0.188 ef & $1.374 \mathrm{bc}$ & $1.853 \mathrm{vd}$ & $0.634 \mathrm{c}$ \\
\hline $100 \% \mathrm{C}+75 \% \mathrm{~K}+75 \% \mathrm{P}+$ Bio-F. & $1.427 \mathrm{~d}$ & $0.116 \mathrm{ij}$ & $1.386 \mathrm{bc}$ & $1.960 \mathrm{a}$ & $0.490 f$ \\
\hline $100 \%$ C + 50 \% K + 50\% P + Bio-F. & $1.427 \mathrm{~d}$ & $0.176 \mathrm{fg}$ & $1.426 \mathrm{a}$ & $1.882 \mathrm{bc}$ & $0.515 \mathrm{e}$ \\
\hline $100 \% \mathrm{C}+25 \% \mathrm{~K}+25 \% \mathrm{P}+$ Bio-F. & $1.453 \mathrm{~d}$ & $0.366 a$ & $1.401 \mathrm{ab}$ & $1.796 \mathrm{e}$ & $0.661 \mathrm{~b}$ \\
\hline $75 \% C+100 \% \mathrm{~K}+100 \% P+$ Bio-F. & $2.127 \mathrm{a}$ & $0.341 b$ & $1.320 \mathrm{~d}$ & $1.895 \mathrm{~b}$ & $0.588 \mathrm{~d}$ \\
\hline $75 \% \mathrm{C}+75 \% \mathrm{~K}+75 \% \mathrm{P}+$ Bio-F. & $2.137 a$ & $0.227 d$ & 1.314de & $1.937 a$ & $0.447 \mathrm{~g}$ \\
\hline $75 \% \mathrm{C}+50 \% \mathrm{~K}+50 \% \mathrm{P}+$ Bio-F. & $1.567 \mathrm{c}$ & $0.316 \mathrm{c}$ & $1.356 c$ & $1.853 \mathrm{~cd}$ & $0.436 \mathrm{gh}$ \\
\hline $75 \% C+25 \% K+25 \% P+$ Bio-F. & $1.567 \mathrm{c}$ & $0.194 \mathrm{e}$ & $1.322 \mathrm{~d}$ & $1.855 \mathrm{~cd}$ & $0.479 f$ \\
\hline $50 \% \mathrm{C}+100 \% \mathrm{~K}+100 \% \mathrm{P}+$ Bio-F. & $1.587 \mathrm{c}$ & $0.124 \mathrm{ij}$ & $1.367 \mathrm{c}$ & $1.896 \mathrm{~b}$ & $0.415 \mathrm{hi}$ \\
\hline $50 \% \mathrm{C}+75 \% \mathrm{~K}+75 \% \mathrm{P}+\mathrm{Bio}-\mathrm{F}$. & $1.287 \mathrm{e}$ & $0.164 \mathrm{~g}$ & $1.355 \mathrm{c}$ & $1.825 \mathrm{de}$ & $0.690 \mathrm{a}$ \\
\hline $50 \% \mathrm{C}+50 \% \mathrm{~K}+50 \% \mathrm{P}+$ Bio-F. & $1.447 \mathrm{~d}$ & $0.127 i$ & $1.225 f$ & $1.805 \mathrm{e}$ & $0.402 \mathrm{ij}$ \\
\hline \multirow[t]{2}{*}{$50 \% \mathrm{C}+25 \% \mathrm{~K}+25 \% \mathrm{P}+$ Bio-F. } & $1.447 \mathrm{~d}$ & $0.146 \mathrm{~h}$ & $1.288 \mathrm{e}$ & $1.799 \mathrm{e}$ & $0.697 a$ \\
\hline & \multicolumn{5}{|c|}{ Second season: $2012 / 13$} \\
\hline Control & $1.427 \mathrm{e}$ & $0.115 \mathrm{~h}$ & $1.282 f$ & $1.812 \mathrm{~g}$ & $0.415 f$ \\
\hline $100 \% \mathrm{C}+100 \% \mathrm{~K}+100 \% \mathrm{P}+$ Bio-F. & $1.563 d$ & 0.197ef & $1.416 \mathrm{e}$ & $1.825 \mathrm{~g}$ & $0.624 \mathrm{~b}$ \\
\hline $100 \% \mathrm{C}+75 \% \mathrm{~K}+75 \% \mathrm{P}+$ Bio-F. & $1.567 \mathrm{~d}$ & $0.223 d$ & 1.579ab & $1.902 \mathrm{~cd}$ & $0.470 \mathrm{e}$ \\
\hline $100 \%$ C + $50 \% \mathrm{~K}+50 \% \mathrm{P}+$ Bio-F. & $1.557 \mathrm{~d}$ & $0.192 f$ & $1.617 \mathrm{a}$ & $1.899 \mathrm{~d}$ & $0.518 d$ \\
\hline $100 \% \mathrm{C}+25 \% \mathrm{~K}+25 \% \mathrm{P}+$ Bio-F. & $1.533 d$ & $0.332 b$ & $1.464 d$ & $1.825 \mathrm{~g}$ & $0.435 f$ \\
\hline $75 \% C+100 \% \mathrm{~K}+100 \% \mathrm{P}+$ Bio-F. & $2.547 a$ & $0.245 c$ & 1.451de & $1.932 b$ & $0.569 \mathrm{c}$ \\
\hline $75 \% \mathrm{C}+75 \% \mathrm{~K}+75 \% \mathrm{P}+\mathrm{Bio}-\mathrm{F}$. & $2.267 \mathrm{~b}$ & $0.227 d$ & $1.507 \mathrm{c}$ & $1.960 \mathrm{a}$ & $0.467 \mathrm{e}$ \\
\hline $75 \%$ C + $50 \% \mathrm{~K}+50 \%$ P + Bio-F. & $2.267 \mathrm{~b}$ & $0.375 a$ & $1.541 \mathrm{bc}$ & $1.882 \mathrm{de}$ & $0.466 \mathrm{e}$ \\
\hline $75 \% C+25 \% \mathrm{~K}+25 \% \mathrm{P}+$ Bio-F. & $1.597 \mathrm{~d}$ & $0.210 \mathrm{de}$ & $1.537 \mathrm{bc}$ & $1.928 \mathrm{~b}$ & $0.488 \mathrm{e}$ \\
\hline $50 \% \mathrm{C}+100 \% \mathrm{~K}+100 \% \mathrm{P}+\mathrm{Bio}-\mathrm{F}$. & $1.987 \mathrm{c}$ & $0.121 \mathrm{~h}$ & $1.610 \mathrm{a}$ & $1.942 a b$ & $0.416 f$ \\
\hline $50 \% \mathrm{C}+75 \% \mathrm{~K}+75 \% \mathrm{P}+$ Bio-F. & 1987c & $0.159 \mathrm{~g}$ & $1.588 \mathrm{a}$ & 1.867 ef & $0.670 \mathrm{a}$ \\
\hline $50 \% \mathrm{C}+50 \% \mathrm{~K}+50 \% \mathrm{P}+$ Bio-F. & $1.987 \mathrm{c}$ & $0.128 \mathrm{~h}$ & $1.415 \mathrm{e}$ & $1.925 \mathrm{bc}$ & $0.676 a$ \\
\hline \multirow[t]{2}{*}{$50 \% \mathrm{C}+25 \% \mathrm{~K}+25 \% \mathrm{P}+$ Bio-F. } & $2.267 \mathrm{~b}$ & $0.347 \mathrm{~b}$ & $1.544 \mathrm{bc}$ & $1.853 \mathrm{f}$ & $0.682 a$ \\
\hline & \multicolumn{5}{|c|}{ Third season: $2013 / 14$} \\
\hline Control & $1.427 \mathrm{i}$ & $0.125 \mathrm{~h}$ & $1.462 \mathrm{i}$ & $1.761 f$ & $0.425 \mathrm{~h}$ \\
\hline $100 \% \mathrm{C}+100 \% \mathrm{~K}+100 \% \mathrm{P}+$ Bio-F. & $2.267 \mathrm{c}$ & $0.219 \mathrm{e}$ & $1.615 \mathrm{e}$ & $1.853 \mathrm{de}$ & $0.611 \mathrm{c}$ \\
\hline $100 \% \mathrm{C}+75 \% \mathrm{~K}+75 \% \mathrm{P}+$ Bio-F. & $1.987 f$ & $0.167 f g$ & 1.627de & $1.950 a$ & $0.515 \mathrm{e}$ \\
\hline $100 \%$ C + 50 \% K + $50 \%$ P + Bio-F. & $2.077 \mathrm{~d}$ & $0.219 \mathrm{e}$ & $1.817 \mathrm{a}$ & $1.914 b$ & $0.575 d$ \\
\hline $100 \% \mathrm{C}+25 \% \mathrm{~K}+25 \% \mathrm{P}+$ Bio-F. & $2.267 \mathrm{c}$ & $0.338 b$ & $1.726 \mathrm{~b}$ & $1.583 \mathrm{de}$ & $0.706 \mathrm{a}$ \\
\hline $75 \% \mathrm{C}+100 \% \mathrm{~K}+100 \% \mathrm{P}+\mathrm{Bio}-\mathrm{F}$. & $2.337 \mathrm{~b}$ & $0.375 a$ & $1.572 \mathrm{fg}$ & $1.882 \mathrm{~b}-\mathrm{d}$ & $0.713 a$ \\
\hline $75 \%$ C + $75 \% \mathrm{~K}+75 \% \mathrm{P}+$ Bio-F. & $2.407 a$ & $0.248 d$ & $1.656 \mathrm{~cd}$ & $1.908 \mathrm{~b}$ & $0.595 \mathrm{c}$ \\
\hline $75 \% C+50 \% \mathrm{~K}+50 \% \mathrm{P}+$ Bio-F. & $1.567 \mathrm{~h}$ & $0.306 c$ & 1.627de & $1.768 f$ & $0.493 f$ \\
\hline $75 \% C+25 \% K+25 \% P+$ Bio-F. & $1.647 \mathrm{~g}$ & 0224e & 1.629de & $1.825 \mathrm{e}$ & $0.512 \mathrm{e}$ \\
\hline $50 \% \mathrm{C}+100 \% \mathrm{~K}+100 \% \mathrm{P}+$ Bio-F. & $1.650 \mathrm{~g}$ & $0.169 \mathrm{fg}$ & $1.666 \mathrm{c}$ & $1.892 \mathrm{bc}$ & $0.475 \mathrm{~g}$ \\
\hline $50 \% \mathrm{C}+75 \% \mathrm{~K}+75 \% \mathrm{P}+$ Bio-F. & $2.057 \mathrm{~d}$ & $0.178 f$ & $1.557 \mathrm{~g}$ & $1.912 \mathrm{~b}$ & $0.649 \mathrm{~b}$ \\
\hline $50 \% \mathrm{C}+50 \% \mathrm{~K}+50 \% \mathrm{P}+$ Bio-F. & $1.987 f$ & $0.155 \mathrm{~g}$ & $1.515 \mathrm{~h}$ & $1.862 \mathrm{~cd}$ & $0.465 \mathrm{~g}$ \\
\hline $50 \% \mathrm{C}+25 \% \mathrm{~K}+25 \% \mathrm{P}+$ Bio-F. & $2.017 \mathrm{e}$ & $0.166 \mathrm{fg}$ & 1.604ef & $1.883 \mathrm{~b}-\mathrm{d}$ & $0.599 \mathrm{c}$ \\
\hline
\end{tabular}

* C: Compost; K: Feldspar; P: Rock phosphate, and Bio-F.: Nitrobeine, Phosphorene and Potasseine.

* Means within a column having the same letters are not significantly different according to Duncan's Multiple Range Test at $5 \%$ level. 


\section{REFERENCES}

A.O.A.C. (1975). Association of Official Agricultural Chemists. "Official Methods of Analysis". $12^{\text {th }}$ Ed., published by AOAC, Washington D.C., USA.

A.O.A.C. (1995)..."Official Methods of Analysis". 16 ${ }^{\text {th }}$ Ed., Association of Official Analytical Chemists. International, Virginia, USA.

Barne, V. G.; Bharad, S. G.; Dod, V. N. and Baviskar, M. N. (2011). Effect of integrated nutrient management on yield and quality of guava. Asian $\mathrm{J}$. of Hort., 6 (2): 546-548.

Bashir, M. A.; Salik, M. R. and Awan, M. Z. (2009). Manure and fertilizers effect on yield and fruit quality of guava. J. of Agric. Res., 47 (3): 247251.

Binepal, M. K.; Tiwari, I. and Kumawat, B. R. (2013). Itegrated approach for nutrient management in guava cv. L.-49 under Malawa plateau conditions of Madhya pradesh. Inter. J. of Agric., Sci., 9 (2): 467-471.

Dashora, L. K.; Rathore, R. S. and Meena, C. L. (2007). Flowering and yield of guava cv. Sardar as influenced by various organic and inorganic sources. Current Agric., 31 (1/2): 67-71.

Devi, H. L.; Mitra, S. K. and Poi, S. C. (2012). Effect of different organic and biofertilizer sources on guava cv. "Sardar". Acta Hort., 959: 201-208.

Dewis, J. and Freitas, F. (1970). Physical and Chemical Methods of Soil and Water Analysis. Food and Agric. Org. of the U.N. (FAO), Soil Buletin No. 10.

Dey, P.; Rai, M.; Kumar, S.; Nath, V.; Das, B. and Reddy, N. (2005). Effect of biofertilizer on physico-chemical characteristics of guava fruit. Ind. J. of Agric. Sci., 75 (2): 95-96.

Duncan, D. B. (1955). Multiple range and multiple F. tests. Biometrics, 11: 1-42.

Dwivedi, D. H.; Lata, R. R. and Babu, M. (2012). Effect of biofertilizers and organic manures on yield and quality of "Red Fleshed" guava. Acta Hort., 933: 239-244.

El-Baz, El. Et. T.; M.A. El-Shobaky; A.A. Loay and and M.A.A. Saleh (2011). Effect of some chemical treatments and hand defoliation on winter production as yield, fruit quality and storage life of Guava. J. Plant Production, Mansoura univ. vol. 2 (3): 467-478, 2011.

Elmehart, H. G.; Ragab, A. A.; Faowaz, Somia, A. and Abotaleb, H. H. (2012). Enhancement of guava fruits quality by using biofertilizers. Annals of Agric. Sci., Moshtohor, 50 (2): 185-192.

El-Sharkawy, Sh. M.M. and Osman, I. M. S. (2009). Evaluation of some guava clones under water preventing conditions at Qalubia governorate. Egypt. J. Appl. Agric. Res., 2 (1): 1-11.

El-Shobaky, M. A. (2007). Effect of irrigation time on harvest date, yield, quality and marketing of guava fruits under drip irrigation in sandy soil. J. Agric. Sci., Mansoura Univ., 32 (9): 7549-7560.

Glick, B. R. (2004). Bacterial ACC deaminase and the alleviation of plant stress. Adv. Appl. Microbiol., 56: 291-312. 
Hernandez, L.; Garcia, Y.; Acosta, J.; Crespo, L.;Daza, N. J.; Pene, M. and Alonso, G. M.; (2013). Arbuscular mycorrhizal fungi, Azotobacter chroococcum, Bacillus megatherium and FitoMa E. an effective alternative for the reduction of mineral fertilizers in guava var. Enana Roja cubana. Cultivos Tropicalos, 34 (1): 5-10.

Horwitz, W. (1970). Official methods of Analysis. Association of Official Analytical Chemists, $11^{\text {th }}$ Ed., Washington D.C., USA.

Jackson, M.L. (1973). Soil Chemical Analysis. Prentice-Hall of India Private Limited M-97, New Delhi, India, 498pp.

Mead, R.; Curnow, R. N. and Harted, A. M. (1993). Statistical Methods in Agriculture and Experimental Biology. $2^{\text {nd }}$ Ed., Chapman \& Hall Ltd., London, $335 \mathrm{pp}$.

Mikhail, E.G.; Osman, I. and Abo El-Khashab, A. Z. (2007). Improving guava (Psidium guajava L.) through fasting and $\mathrm{K}$-and $\mathrm{Ca}$-citrate application. The $3^{\text {rd }}$ Conf. of Sustain. Agric. Develop., Fac. Agric., fayoum Univ., 1214 Nov., 197-206.

Mitra, S. K., Gurung, M. R. and Pathak, P. K. (2010). Integrated nutrient management in high density guava orchards. Acta Hort; (849):349-356.

Muhammad, F.; Shakir, M. A. and Salik M. R. (2000). Effect of individual and combined application of organic and inorganic manures on the productivity of guava (Psidium guajava L.). Pakistan J. of Bio. Sci., 3 (9): 1370-1371.

Nunes, J. C.; Cavalcante, L. F.; Lima Neto, A. J.; deSilva, J. A.; da Souto, A. G. and Rocha, L. F. da (2014). Humic substances and soil mulching on initial growth of guava cv. "Paluma" in experimental area. Agro @ mbiente on-line, 8 (1): 89-96.

Ram, R. A.; Singha, A. and Bhriguvanshi, S. R. (2014). Response of on farm produced organic inputs on soil, plant nutrient status, yield and quality of guava cv. Allahabad Safeda. Indian J. Agric. Sci., 84 (8): 962-967.

SAS, Institute. (1994). SAS/STAT User's Guides Statistics. Vers. 6.04, $4^{\text {th }}$ Ed., SAS. Institute Inc. Cary, N.C., USA.

Singh, G. (2007). Recent development in production of guva. Inter. Guava Sympos., ISHS Acta Hort., 753.

Thonte, G. T. and Chakrawar, V. R. (1982). Physico-chemical characters of the certain types/strains of guava (Psidium guajava L.). Progressive Hort., 14: 269-272.

Wali, V. K.; Bakshi, P. and Jamwal, M. (2011). Effect of organic manures and biofertilizers on leaf and fruit nutrient status in guava cv. Sardar. J. of Hort. Sci., 6 (2): 169-171.

Wide, S. .; Corey, R. B.; Lyer, J. G. and Vioget, G. (1985). Soil and Plant Analysis for Tree Culture, $3^{\text {rd }}$ Ed., Oxford, IBH Publishing Co., New Delhi, pp. 93-116.

Yadav, R. I.; Singh, R. K.; Jat, A. L.; Choudhary, H. R. and Kumar, V. P. P. (2013). Effect of nutrient management through organic sources on productivity and profitability of guava under Vindhyan region. Environment and Ecology, 312(A): 735-737. 


\section{تأثير بعض معاملات التسميد على نمو وإنتاج وجودة ثمار الجوافة (صنف عتمانى).

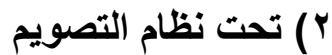 إبراهيم محمد سيد عثمان ، عبد التبد العزيز أحمد الطويل وعماد جرجس ميخائيل

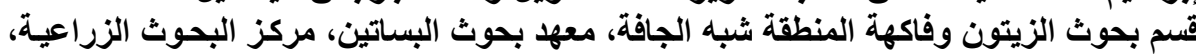

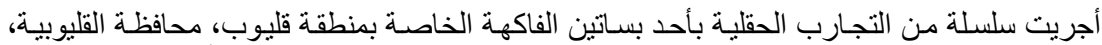

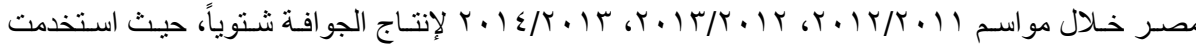

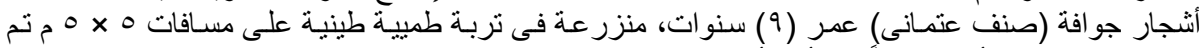

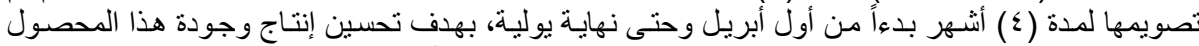

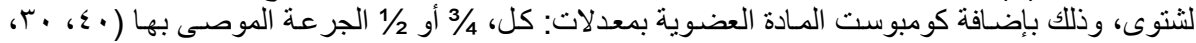

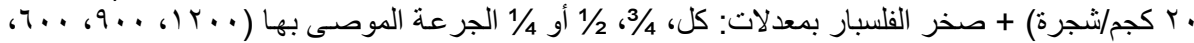

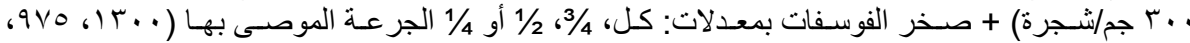

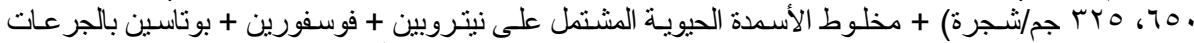

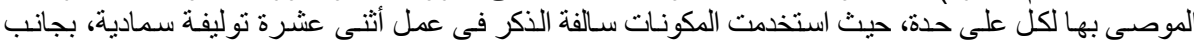
المقارنة (بدون تسميد).

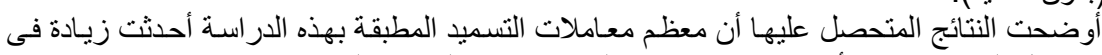

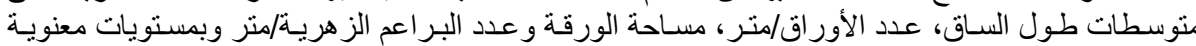

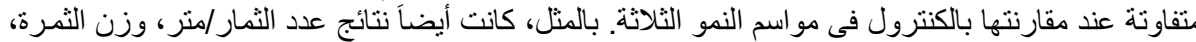

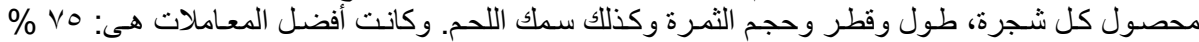

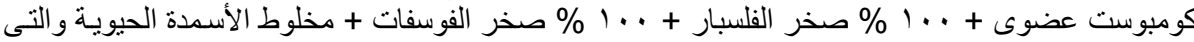

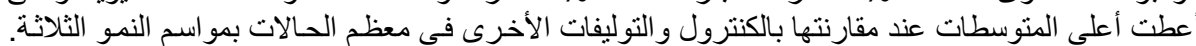

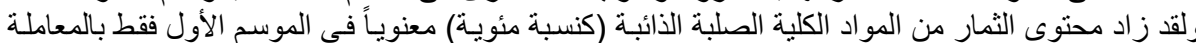

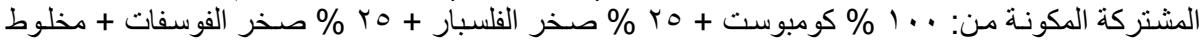

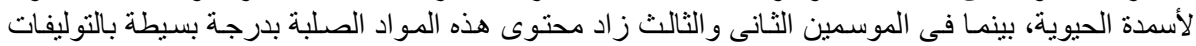

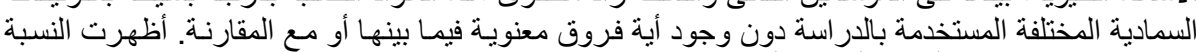

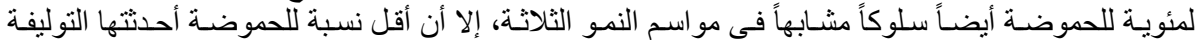

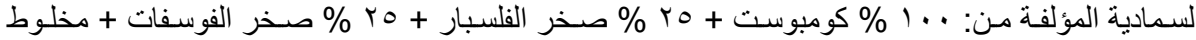

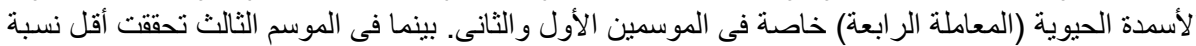

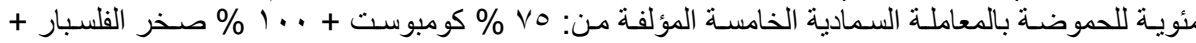

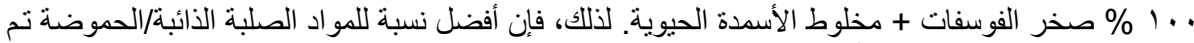

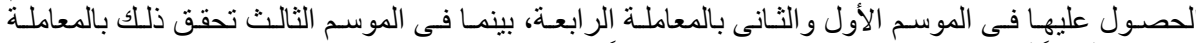

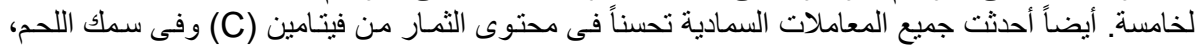

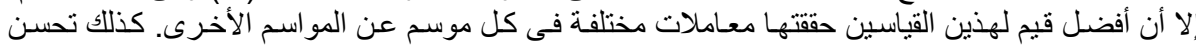

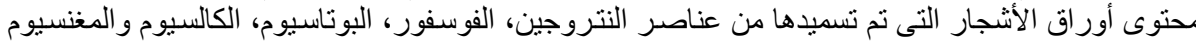

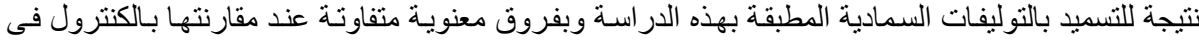

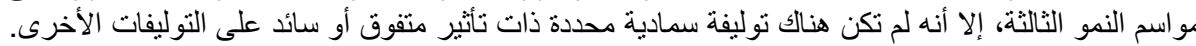

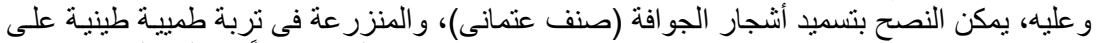

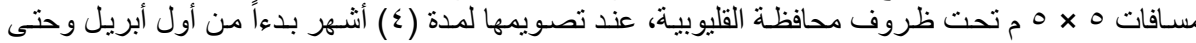

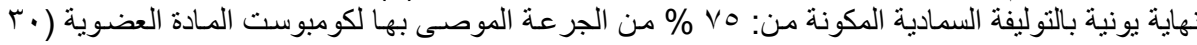

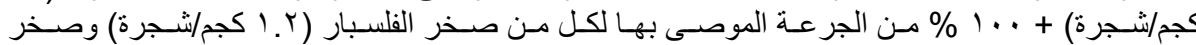

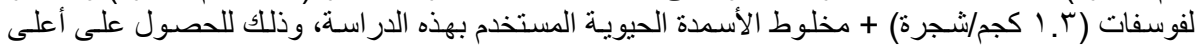

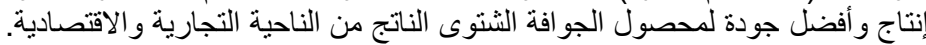


Table (4): Effect of fertilization treatments on some vegetative growth traits and No. flower buds of (Psidium guajava

L.) "Etmani" cv. tree under fasting system during 2011/12, 2012/13 and 2013/14 seasons.

\begin{tabular}{|c|c|c|c|c|c|c|c|c|c|c|c|c|}
\hline \multirow{2}{*}{ Treatments } & \multicolumn{3}{|c|}{ Shoot length (cm) } & \multicolumn{3}{|c|}{ No. of leaves/lm } & \multicolumn{3}{|c|}{ Leaf area $\left(\mathrm{cm}^{2}\right)$} & \multicolumn{3}{|c|}{ No. flower buds/lm } \\
\hline & 201/12 & 2012/13 & $2013 / 14$ & 201/12 & 2012/13 & 2013/14 & 201/12 & 2012/13 & $2013 / 14$ & 201/12 & 2012/13 & \begin{tabular}{|l|l|l|}
$2013 / 14$ \\
\end{tabular} \\
\hline Control & $17.40 \mathrm{~cd}$ & $19.20 \mathrm{~b}$ & $18.08 \mathrm{bc}$ & $42.14 \mathrm{i}$ & $42.37 \mathrm{~h}$ & $50.81 \mathrm{~h}$ & $31.37 \mathrm{c}$ & $31.46 \mathrm{e}$ & $29.76 f$ & $19.82 h$ & $21.98 \mathrm{~g}$ & $24.64 \mathrm{~g}$ \\
\hline $100 \% \mathrm{C}+100 \% \mathrm{~K}+100 \% \mathrm{P}+$ Bio-F. & $19.23 \mathrm{~b}$ & $18.30 \mathrm{bc}$ & $18.62 b$ & $53.93 \mathrm{~h}$ & $60.48 \mathrm{~g}$ & $65.19 \mathrm{~g}$ & $40.06 a b$ & $53.59 a$ & $55.44 a$ & $26.00 \mathrm{fg}$ & $30.54 b$ & d $29.90 f$ \\
\hline $100 \% \mathrm{C}+75 \% \mathrm{~K}+75 \% \mathrm{P}+\mathrm{Bio}-\mathrm{F}$. & $17.57 \mathrm{c}$ & 18.17c & $17.87 \mathrm{c}$ & $85.45 \mathrm{c}$ & 97.07ab & $97.59 \mathrm{bc}$ & $38.65 \mathrm{bc}$ & $46.36 \mathrm{ab}$ & $53.70 a b$ & $29.81 \mathrm{~cd}$ & $31.20 \mathrm{bc}$ & $34.71 \mathrm{~b}$ \\
\hline $100 \% \mathrm{C}+50 \% \mathrm{~K}+50 \% \mathrm{P}+\mathrm{Bio}-\mathrm{F}$. & $18.63 \mathrm{~b}$ & $18.13 c$ & $17.82 \mathrm{c}$ & $79.60 d$ & $93.95 \mathrm{bc}$ & $99.16 a-c$ & $41.53 a b$ & $42.53 b-d$ & $49.31 \mathrm{a}-\mathrm{d}$ & 28.09de & 30.87 & $32.55 \mathrm{de}$ \\
\hline $100 \% \mathrm{C}+25 \% \mathrm{~K}+25 \% \mathrm{P}+$ Bio-F. & $17.03 \mathrm{c}-\mathrm{e}$ & $17.57 \mathrm{~cd}$ & $17.65 \mathrm{c}$ & $93.37 a$ & $97.01 \mathrm{ab}$ & $100.57 a-c$ & $40.44 a b$ & $48.16 \mathrm{ab}$ & $51.01 a-c$ & $29.95 \mathrm{~cd}$ & $30.55 b-d$ & $\mathrm{~d} 33.46 \mathrm{~b}-\mathrm{d}$ \\
\hline $75 \%$ C + $100 \% \mathrm{~K}+100 \% \mathrm{P}+$ Bio-F. & $21.40 \mathrm{a}$ & $22.73 a$ & $19.48 \mathrm{a}$ & 91.09ab & $99.33 a$ & $103.80 a$ & $47.95 a$ & $45.87 \mathrm{bc}$ & $54.04 a$ & $33.42 a$ & $33.16 \mathrm{a}$ & $37.12 \mathrm{a}$ \\
\hline $75 \%$ C + $75 \%$ K + $75 \%$ P + Bio-F. & 16.27ef & $16.03 \mathrm{e}$ & $16.98 \mathrm{bc}$ & 75.86de & $81.09 d$ & $87.97 d$ & $38.81 \mathrm{bc}$ & $41.50 \mathrm{~b}-\mathrm{d}$ & $44.13 c-e$ & $31.98 \mathrm{ab}$ & $32.46 \mathrm{ab}$ & $34.58 \mathrm{bc}$ \\
\hline $75 \% \mathrm{C}+50 \% \mathrm{~K}+50 \% \mathrm{P}+\mathrm{Bio}-\mathrm{F}$. & $17.53 \mathrm{c}$ & $17.93 c$ & $17.65 \mathrm{c}$ & $92.00 \mathrm{a}$ & $95.73 a-c$ & $100.30 a-c$ & $38.50 \mathrm{bc}$ & $41.87 \mathrm{~b}-\mathrm{d}$ & $44.50 \mathrm{c}-\mathrm{e}$ & $24.71 \mathrm{~g}$ & $26.94 f$ & $30.21 f$ \\
\hline $75 \% C+25 \% K+25 \% P+$ Bio-F. & $18.37 \mathrm{~cd}$ & $18.23 \mathrm{bc}$ & $18.02 \mathrm{c}$ & $70.69 f$ & 71.92ef & $79.00 \mathrm{e}$ & $38.12 \mathrm{bc}$ & 35.41de & $40.31 \mathrm{e}$ & $27.06 \mathrm{ef}$ & $30.00 \mathrm{~cd}$ & $32.75 c-e$ \\
\hline $50 \%$ C + $100 \%$ K + $100 \%$ P + Bio-F. & $16.47 \mathrm{~d}-\mathrm{f}$ & $17.73 \mathrm{~cd}$ & $17.83 \mathrm{c}$ & $65.80 \mathrm{~g}$ & $68.52 f$ & $74.03 f$ & $42.35 a b$ & 36.05de & $38.91 \mathrm{e}$ & $27.16 \mathrm{ef}$ & $27.63 \mathrm{ef}$ & $30.85 \mathrm{ef}$ \\
\hline $50 \% \mathrm{C}+75 \% \mathrm{~K}+75 \% \mathrm{P}+\mathrm{Bio}-\mathrm{F}$. & $15.83 f$ & $17.47 \mathrm{~cd}$ & $17.55 \mathrm{~cd}$ & $94.85 a$ & $92.79 c$ & $97.28 \mathrm{c}$ & $47.96 a$ & $38.65 \mathrm{c}-\mathrm{e}$ & $41.73 \mathrm{de}$ & $31.18 \mathrm{bc}$ & $31.30 \mathrm{bc}$ & $33.25 b-d$ \\
\hline $50 \% \mathrm{C}+50 \% \mathrm{~K}+50 \% \mathrm{P}+\mathrm{Bio}-\mathrm{F}$. & 16.33ef & 16.87de & $17.47 \mathrm{~cd}$ & $86.54 \mathrm{bc}$ & 97.64ab & $102.53 a b$ & $43.29 \mathrm{ab}$ & $38.52 \mathrm{c}-\mathrm{e}$ & $41.57 \mathrm{de}$ & $26.52 \mathrm{e}-\mathrm{g}$ & g 28.05ef & $30.16 f$ \\
\hline $50 \% \mathrm{C}+25 \% \mathrm{~K}+25 \% \mathrm{P}+\mathrm{Bio}-\mathrm{F}$. & $16.67 \mathrm{c}-\mathrm{f}$ & $17.80 \mathrm{~cd}$ & $17.60 \mathrm{c}$ & 71.68ef & $73.05 \mathrm{e}$ & $84.80 \mathrm{~d}$ & $37.44 \mathrm{bc}$ & $42.79 b-d$ & $46.04 \mathrm{~b}-\mathrm{e}$ & $28.19 \mathrm{de}$ & $29.16 \mathrm{de}$ & $31.52 d-f$ \\
\hline
\end{tabular}

* C: Compost; K: Feldspar; P: Rock phosphate, Bio-F.: Nitrobeine, Phosphorene, Potasseine and Im: Longitudinal meter.

* Means within a column having the same letters are not significantly different according to Duncan's Multiple Range Test at $5 \%$ level. 